Ambient Science, 2018: Vol. 05(Sp1); 07-10

DOI:10.21276/ambi.2018.05.sp1.ga02

\title{
Industrial Development and Strategic Staff Displacement: A Report on the Crises Facing by the Displaced People of Rourkela Steel Plant, Odisha, India
}

\section{Purna Chandra Pradhan \\ Department of Anthropology, Vinoba Bhave University, Hazaribag, Jharkhand, India \\ Study Area: Rourkela, Sundergarh District, Odisha, India Coordinates: $22^{\circ} 14^{\prime} 57^{\prime \prime} \mathrm{N} ; 84^{\circ} 52^{\prime} 58^{\prime \prime} \mathrm{E}$}

Key words: Orissa, Rehabilatation, Land Resources, Labour,

\section{Introduction:}

Every year more than 10 million people in different parts of the world are involuntarily displaced from their traditional hearth and home to make way for development projects. Indisputably such development projects are needed to improve the lives of people, but at the same time, all such projects denunciate the rights of displaced people to social justice and equality when due attention is not given for their proper rehabilitation and resettlement (Meher, 2001a,b).

Under the above backdrop, the present study was designed to explicate the socio-economic conditions of the oustees of Rourkela Steel Plant.

The survey study was mainly based on direct and participatory observation of total 4 resettlement colonies within a distance of $20 \mathrm{~km}$ from Rourkela Steel Plant. During the survey, we carried out, the Interview Schedules, Case Study, In-depth Interviews, Primary Data Collection, and Direct Observation as tools. The total samples were restricted to 300 households belongs to the displaced people of 4 villages. Data were analyzed statistically. Collection of primary data were done on the basis of area of the survey and was evaluated by available secondary data available (Census of India, 2001).

Background history of setting up Rourkela Steel Plant(RSP):

In the year 1950, the proposed setting up a steel plant at Rourkela was started which was a backward and least industrialized area of the State of Odisha. The objective was that the plant would generate employment to the people of

\section{Abstract}

Industrialisation has brought numerous progressions on the financial status of the general population especially who are dwelling in urban territories. With the pace of improvement, there is a social cleavage - that is the rich are getting to be more extravagant and the poor are getting to be poorer. This has created genuine threats to the urban populace, especially for the tribals. Rourkela has developed as a very modernized city resulting in substantial scale impact on the indigenous people in terms of occupation and prosperity. This study attempts to analyze the effects of industrialization on the socio-economic conditions of the tribal people in and around Rourkela city.

the state. The land acquisition process for the Rourkela Steel Plant (RSP) was started in the year 1954 and continued up to 1976. According to the report of the Revenue Department, Government of Orissa for the RSP and its township all total 7,889 $\mathrm{Ha}(19,722,69$ acres) land was acquired from 33 villages. Of the total acquired land, the government land was $24.84 \%(4898.51$ acres $)$ and the remaining was the private property $(75.16 \%)$. This resulted in direct displacement of 2,901 families, out of which 1,974 $(68.05 \%)$ were scheduled tribes (STs) or tribal and 279 ((9.62\%) were scheduled castes (SCs). Further in order to provide water to the plant and colony, a water reservoir was built on river Sankh at Mandira around $30 \mathrm{~km}$ away from the plant site. The construction of the Mandira dam on river Sankh further affected 31 tribal villages and displaced 1,193 families. The total land acquired for the dam purpose was around 4,786 Ha (11,964 acres), Thus, RSP in Odisha caused direct displacement of 4,094 families and acquisition of 12,675 Ha lands that included prime agricultural land of the acquired tribal villages (Census of India, 2001).

Socio-Economic Condition of people of Rourkela before RSP:

The data reveals that before the setting up of the RSP, this region had $84.8 \%$ of agriculturally based families and $15.2 \%$ of non-agricultural families. The landowners in the Rourkela region constituted $78.7 \%$ of the total number of households and hardly $4.6 \%$ as a landless labourer. While agriculture was the principal means of livelihood of $84.3 \%$ tribal families, among the general caste Hindus $76.1 \%$ families were reporting agriculture as their principal means 
of livelihood and among the scheduled castes the percentage of such families was $72.6 \%$. The average size of land holding was 8 acres in the region as compared to 7.9 acres in Sundargarh district and 5.1 acres in Odisha during the early 1950s. (Meher, 2003, 2004).

\section{Displacement and rehabilitation myth or reality:}

When land was acquired for this project the displaced households were given nominal cash compensation for the loss of house and properties and one of the male members of the undivided family was assured to be given employment in the project. Added to that in some cases the oustee households were given land for resettlement in the colonies and also agricultural land especially in the case of some among the oustee families of Rourkela in Odisha. However, it is found that many in the present generation are dissatisfied with the major taken by public sector steel plants and the descendants of the oustees still found running from pillar to post to get justice and in many cases their resentments and dissatisfactions were shown against the state in the form of protests and militancy demanding more cash compensation, return of unused surplus land of the project to oustee families and jobs for living and livelihood of the next generation (Mahapatra,1999).

The socio-economic status of the displaced people before and after land acquisitions: out of a total of 300 respondents, $220(73.33 \%)$ were males and 8o (26.67\%) were females. Further, the majority $(70.32 \%)$ of the land oustees were from the Scheduled Tribe community, 8.58\% were from Scheduled Caste and the rest $(21.11 \%)$ belong to Other Lower caste.

\section{Disruption of Formal Educational Activity:}

Majority of the respondents were from rural and tribal areas, where the literacy rate is very low and out of 300 heads of households, $220(73.33 \%)$ were illiterate 66 (22\%) respondents had education up to primary standard,14 (4.67\%) respondents had education up to 1oth standard. The present study further revealed that 77 (25.56\%) left school due to economic hardship, $13(4.44 \%)$ due to inconvenient distance of school, $42(14.17 \%)$ could not go to school due to work at home, $54(18.06 \%)$ work as child labour, $73(23.89 \%)$ said that the new place did not have school. Remaining 41 (13.89\%) did not attend school mainly because of malnutrition and poor health. So it could be concluded that drop-out rates have become high due to acute poverty and deprivation which did not allow parents to send their children to school. The female child often had to drop out of school due to work at home in most of the oustee's families.

\section{Family Pattern:}

The family structure of the displaced people showed that more than three-forth, 255 ( $85 \%)$ maintain nuclear families at present, whereas such families were 180 (6o\%) before land acquisition. It is clearly evident that land acquisition has brought about a split in the families, as people went to several places outside their native place in search of occupation. There are only $30(10 \%)$ joint families after the land acquisition as against 90 (30\%) joint families before the land acquisition, the average size of the joint family has also come down. The extended families are $9(3 \%)$ after land acquisition, while they were $27(9 \%)$ before land acquisition.

\section{Compensation, occupation and income:}

In response to a question about receiving compensation for their house, land and other assets, $210(70 \%)$ of the respondents said "yes" (received money), but 9o (30\%) replied in the negative, (did not receive any compensation).

Acquisition of land resulted in certain changes in the situations related to the occupation of the affected people. Out of 300 respondents, $6.67 \%$ were agriculturist and nearly $16.67 \%$ was an agricultural labourer. A significant number of displaced people (73.33\%) now work as unskilled laborers. Only 2 of them working as a government teacher, 5 (1.67) as Anganbadi employees, 3 (1\%) work in the private sector. It has been observed that there are marked changes in the occupational life and the place of work of the people affected by the land acquisition. Most of the people now gone towards the main city area for the increasing age of the young persons. Monthly Income of Family Members.

More than $52.76 \%$ and $53.16 \%$ people do not have any income before and after land acquisition. The monthly income of individuals earning less than Rs.200o was 18.71\% and $18.67 \%$ respectively before and after land acquisition. There were $14.97 \%$ people who had monthly income in between Rs. 2001-5000, prior to land acquisition and had been reduced to $14.68 \%$ after land acquisition. There were $11.96 \%$ people in Rs. 5001 to 8000 category before land acquisition and $11.39 \%$ people after land acquisition. There were $0.98 \%$ people in Rs. 8001 to Rs.110oo categories before land acquisition and $\mathbf{1 . 2 0} \%$ people after land acquisition. There were $0.61 \%$ and $0.81 \%$ people, whose income was in the range of Rs.110oo and above before land acquisition.

There is a striking change in the individual monthly income level of all category of people. Therefore, it could be stated that there is an improvement in the number of people in high-income groups. This clearly proves the emergence of new classes as well as sharpening of class boundaries among the displaced people of Rourkela. Many families were keeping their expenditures within their income limits but those whose expenditure exceeded their incomeare ending up with debts.

\section{Land ownership pattern of family members:}

Among the 300 respondents, $97.66 \%$ were seen to be the landless laborers after displacement whereas the number of such people was only $26.67 \%$ before displacement. It appears that many of them were earlier marginal farmers, as compared to the present condition of $2.33 \%$. The 
proportion of small farmers had also declined from 30 to o\% earlier. Thus, all categories of land ownership had suffered as compensation was not always utilized to buy land by the oustees. One reason for this was the high price of land in neighboring villages where non-tribal people live. Obviously, it proves the limit of cash compensation alone to rehabilitate the marginalized people.

Land acquisition in tribal area indicates change in the economic position of the Displaced people. About 30\% of the interviewed displaced persons assessed their economic position as very low or low before land acquisition. Post land acquisition scenario depicts an intensification of a trend towards marginalization. Thus percentage of respondents in these categories increased to $62.33 \%$ after land acquisition the position of those in the low \& medium category also declined from 68.33 to $32.66 \%$ during the same period. This clearly reveals the negative effect of land acquisition on the economic status of affected people.

\section{Tradition and Change:}

Out of 300 respondents, 53 (17.67) have stated that they have undergone psychological disorder. Among them, 20 $(37.74 \%)$ belong to the landless category, $30(56.60 \%)$ were from Marginal farmer categories. Thus, it could be stated that most of the people who had psychological disorder belong to the landless and marginal farmer category. These people had stated the reason for their psychological disorder to be land acquisition, loss of livelihood and financial problems.

Since tribal are innocent and illiterate, money-lenders tried to exploit them easily by giving money at higher interest. There were recorded also some instances where a person fails to repay the debt within a stipulated time were forced to work in the field/shop. As a result, a kind of patron-client relationship has emerged in the new set up which is completely alien to the tribal culture.

\section{Rehabilitation and resettlement policy:}

The overall RSP rehabilitation and resettlement policy proved to be highly complicated, confusing and at the same time deceptive. The land-for-land based rehabilitation was not done in a proper way. Employment generation was initiated but there was little effort to achieve the goal set effectively. The mode of providing compensation through cash was only for those who have title deeds of the land. This policy also did not specify how displacement would be kept at the minimum. Interestingly, compensation (included money and offered jobs) was given only to them who had an ownership right on the land and whereas, persons having a problem in succession and inheritance were compensated by money and not through jobs in RSP. As a consequence, many displaced persons remained outside the purview of the complete compensation package given by the company. Complete rehabilitation was not done by RSP management. The present study reveals that the RSP management had tried to resettle the displaced people at various places like Jalda, Jhirpani, Ambagaon, etc., but it did not get possible as the local people objected to the entry of additional people. A large majority of those interviewed were actually left their original Home when they were forced to vacate and most of them did not make any objection to it as there was no alternative before them. Although RSP management had given employment to some adults of the affected families and deposited the compensation amount in a few people's accounts for building houses, nothing more was done. As a result of a casual approach followed by the management towards proper rehabilitation and resettlements of the oustees, it was noticed there were several protesting activities including gherao of district Authorities by the displaced people. Displacement not only evicts the owner from the land and destroys their livelihood and employment opportunities but also affects the families of the agricultural laborers, domestic laborers, and artisans (Blacksmiths, carpenters, cobblers etc.). milkmen, tillers, harvesters, cow and goat rearers, and flower and vegetable vendors. The demand for farm labour work has become more fluctuating and uncertain. After displacement, a landless labourer is much more uncertain about his income at the beginning of a month. These groups of people who were dependent on land and land owners indirectly lose their right to life, security, employment and livelihood opportunities.

The study reveals that the land acquisition has affected the social, economic religious and political life of the oustees very badly. Thus, to begin with, economic constraints and changes in land ownership pattern forced the oustees to abandon joint and extended families and start nuclear and single units. Land acquisition had also brought about a split in the families as people went to several places in search of livelihood. The rise of singleheaded families since displacement signifies breakdown of social relations and social bonds that hardly characterize the life of tribal and other communities. Simultaneously, there has been marked a change in the occupational life and the place of work of the people affected by the land acquisition.

\section{Negative impacts after displacement:}

Initially, it has been seen that there was a temporary rise in employment, which was associated with project construction activities. But these options declined rapidly once Manual task in the project came to an end. Gradually unemployment or underemployment engulfed the resettlers leading to their impoverishment. Unemployment and Underemployment pushed displaced people to seek options of seasonal migration and inter-state migration including options like bonded or child laborer for the minors. Involuntary resettlement has led to increased social stress, insecurity, physiological trauma and the outbreak of relocation related illness, particularly malaria 
and dengue. Unsafe water supply and poor sewerage system increase vulnerability to epidemics and chronic diarrhea, dysentery and so on. The weakest segment of the demographic spectrum-infants, children and the elderly are affected most strongly. The present study reveals that all most all the inhabitants were using ponds, river, small stream water and dug well for drinking purpose before displacement. Now 70.08\% of displaced people are using Government-supplied water and the rest 30\% are still using dug well, stream and river water for their drinking purpose. The compensatory jobs were given by RSP mainly had gone to men. It has been found that husband and son were only the beneficiaries of such jobs. Although RSP did not restrict workmen from getting the compensatory jobs, yet because of prevailing patriarchal notions, men (Husbands and sons) were the beneficiaries. Even those women, who did receive manual jobs initially, were thrown out of such temporary jobs after technological up-gradations and mechanization of RSP. Whatever little skilled or semiskilled employment was given to the selected persons by RSP, these went to men as labourer, fitter, Helper etc. Women were also given jobs that are unskilled and low paid and often on the daily wage basis. Jobs being scarce with the project, the first casualty was the women because they lack skill and do not normally protest. Again in the face of competition between family members due to the scarcity of jobs, the women tend to lose out, often almost voluntarily.

Displacement has destroyed the custom, dialects, lifestyle, and values. Being deprived of their land, in search of work tribal women along with their husband migrated to the urban center. But migration disrupts harmonious family and village life. These migrant families are not able to utilize the opportunity offered by the various scheme of the tribal development departments.

\section{Policy Implications:}

Nationwide the displacement of people caused by developmental projects is always considered a serious issue. Now the question arises is how the displaced people would be provided with a better deal and what should be the responsibility of the institution in this regard. Perhaps this query can be responded well in terms of rehabilitation. However, it is evident in the case of RSP and similar other instances that the costs of displacement can never be met by cash compensation alone. The small sum received as compensation is soon exhausted and it does not provide a long-term source of income. The solution is to allow the displaced people to share the benef its of development first. Resettlement as a consequence of displacement can be positive when it is seen and planned as an opportunity to improve the livelihood of those displaced by investing in their development and not only by compensating theirs loses. Involving people displaced from their land as partners in development projects will not only remove conflicts but also ensure a more equitable development process. This would ensure the fact that people are important to projects.

\section{Suggestions for rehabilitation facilities:}

The Debar Commission's recommendation explained that a permanent mechanism for a study of every individual project and its impact on tribal interest should be set up. The scheme of rehabilitation and resettlement should be an integral part of the project. The time lag between displacement and rehabilitation shall be minimized. It should be the responsibility of the project authority to provide basic facilities like the house, drinking water, sanitation, school, road, hospitals etc. It laid emphasis on technical education and attached high priority to absorption of the tribal people in permanent employment. Thus, the government should make national policy on rehabilitation by considering World Bank, JADB and Dhebar Commission Recommendation. The National Policy on Rehabilitation and Resettlement 2007 Bill was passed by Lok Sabha and placed in an upper house of parliament, but the Bill lapsed due to the expiry of 14th Lok Sabha. The rehabilitation and resettlement should consider social and cultural factors while providing sustainable means of livelihood. Moreover, the people must be compensated on "a land for land" (Pani, 2007).

\section{Acknowledgment:}

I would like to express my deep appreciation and gratitude to all those who have contributed to this work. It was the great reverence for me to work with Dr GN Jha, for suggesting me this area of work and cooperation. I am extremely obliged to Dr R K Meher, Prof.NK Chaudhury Inst. of Soc. Sci., Bhubaneswar for giving me an exposure on various methodological problems during study.

\section{References:}

Census of India (2001): C-8 Educational Level By Age And Sex For Population Age 7 And Above. Online pub. by: Off ice of the Registrar General \& Census Commissioner, India.

Mahapatra, L.K. (1999): Resettlement, impoverishment, and reconstruction in India: development for the deprived. Pub. by: New Delhi, Vikas Publishing House. 184 p.

Meher, R. (2003): The Social and Ecological Effects of Industrialization in a Tribal Region. The Case of the Rourkela Steel Plant. Contrib. Indian Soc., 37(3):429-57.

Meher, R. (2004): Stealing the Environment: Social and Ecological Effects of Industrialization in Rourkela. Pub. by: Manohar, New Delhi, India.

Mehar, R. (2001a): Impact of Economic Liberalization on the Backward States and Weaker Sections of Population in India. Fourth World,14:58-86.

Mehar,R (2001b): Degeneration of the Periphery under Hegemonic Development: The Case of Marginalization of the Aboriginal in a Tribal Region. Indian Soc. Sci. Rev., 3(2):289-326

Pani, S.C. (2007): National Rehabilitation and Resettlement Policy, 2007. Resolution Pub. by: Ministry of Rural Development, Department of Land Resources \&Land Reforms Division, Govt. of India. 28 p. 